\title{
Economics of emu farming in Marathwada region of Maharashtra
}

V.G. LANDGE, D.N. HEDGIRE, R.A. KOLAMBKAR AND P.R. MULE

Received : 13.08.2014; Revised : 18.08.2014; Accepted : 30.08 .2014

\begin{abstract}
The data on selected economic aspects were collected by interviewing the respondent farmers in the Marathwada region of Maharashtra state. The fixed capital investment for sampled emu farmer was Rs. 269447.82. The share of emu bird pairs was Rs. 213110.02 (79.09\%), land invested to Rs. 35357.10 (13.12\%), emu farm establishment cost was Rs. 19805.70 (7.35\%). The amount contributed by equipments and appliances was Rs. $1175.00(0.44 \%)$. The fixed capital investment for emu farm was Rs. 998645. The share of emu bird pairs was Rs. 750000 (75.10\%), land invested. Rs. 200000 (20.02\%), emu farm establishment cost was Rs. 47200 (4.72\%). The amount contributed by equipments and appliances was Rs. $1445(0.16 \%)$. It was observed that total cost of emu farming was Rs. 195855.97. The per pair of emu bird, the cost was Rs. 13851.18. The total variable cost accounted Rs. 135693.16. The variable cost per pair of emu bird was Rs. 9596.40.
\end{abstract}

KEY WORDS : Economics, Emu farming, Cost, Investment, Returns

How to cite this paper : Landge, V.G., Hedgire, D.N., Kolambkar, R.A. and Mule, P.R. (2014). Economics of emu farming in Marathwada region of Maharashtra state. Internat. J. Com. \& Bus. Manage., 7(2) : 305-310.

\section{MEMBERS OF THE RESEARCH FORUM}

Correspondence to:

V.G. LANDGE, Department of Agricultural Economics, College of Agriculture, Vasantrao Naik Marathwada Krishi Vidyapeeth, PARBHANI (M.S.) INDIA

Email: varshalandge002@gmail.com

Authors' affiliations:

D.N. HEDGIRE AND R.A. KOLAMBKAR, Department of Agricultural Economics, College of Agriculture, Vasantrao Naik Marathwada Krishi Vidyapeeth, PARBHANI (M.S.) INDIA

P.R. MULE, Department of Animal Husbandry and Dairy Science, College of Agriculture, Vasantrao Naik Marathwada Krishi Vidyapeeth, PARBHANI (M.S.) INDIA 